\title{
The Investigation of Influenza and Related Viruses in the Electron Microscope, by a New Technique
}

\author{
By I. M. DAWSON AND W. J. ELFORD \\ National Institute for Medical Research, London, N.W. 3.
}

SUMMARY: Influenza and related viruses were studied by a new method in which virus is adsorbed on the membranes of laked fowl red cells for examination in the electron microscope. The numbers of virus particles adsorbed per unit area of red-cell membrane were estimated from direct counts in micrographs of palladium-shadowed and unshadowed specimens. There was a definite saturation level of adsorption for each strain of virus, the value varying also according to the particular batch of cells and their age after storage at $0^{\circ}$. For subsaturation conditions the number of particles adsorbed was proportional to the concentration of virus and the concentration of cells, and a function both of time of contact and temperature. The relationships were complicated by the fact that elution began before adsorption was complete.

The comparative data for the size and variation of these viruses were obtained from micrographs of preparations directly adsorbed from infective allantoic fluid and thus not subjected to harsh methods of purification. The mean sizes $(m \mu)$ found for the dried virus were: influenza $A$ virus, $90 \pm 11.5$; influenza $B$ virus, $103 \pm 8$; fowl-plague virus, $101 \pm 16$; Newcastle-disease virus, $193 \pm 28$; and mumps virus, $179 \pm 28$.

The occurrence of long forms associated with influenza $B$ virus was confirmed and filamentous structures were demonstrated for the first time in preparations of a strain of fowl-plague virus.

The red-cell agglutination first described by Hirst (1941, 1942) and McClelland \& Hare (1941) for influenza virus and fowl erythrocytes has proved of great value as a basis for the assay of influenza and related viruses. Attempts to elucidate the process of this agglutination have given some information on the mechanism of attack of a virus on a susceptible cell, particularly on the initial phases of adsorption and penetration. An excellent survey of the lines of approach so far taken in this vital problem has been recently given by Burnet (1948). Our own interest in this field developed during investigations of the physical properties of the influenza, Newcastle disease, fowl plague and mumps group of viruses (Elford, Chu, Dawson, Dudgeon, Fulton \& Smiles, 1948), where the haemagglutination test was extensively applied, and it was thought that the process would be more clearly understood if direct optical evidence of the mechanism were obtained. The sizes of the viruses, $70-150 \mathrm{~m} \mu$, lie on both sides of the limit of resolution of the ultra-violet light microscope. In some ultra-violet micrographs of the virus of Newcastle disease, taken in collaboration with our colleagues, Mr J. Smiles and Mr F. W. Welch, some adsorbed bodies were demonstrable in $0 \cdot 1 \mu$ optical sections taken through the cell; but the limitations of the method were such that no convincing evidence was forthcoming. The electron microscope appeared to be the obvious tool for the study, the resolution being more than adequate; and the sole requirement for its use being a suitable method of preparing the specimen.

We were interested in the haemagglutination phenomenon for another reason. 
In our early electron microscope studies of the morphology of the viruses of this group we had to examine material which had been purified by prolonged centrifugation at high speeds. The effects of such strong gravitational fields on virus morphology were quite unknown, but it was suspected that a considerable amount of distortion could take place. Although we had a reasonably good correlation between infectivity and the numbers of particles seen on the micrograph, we were uncertain whether all the material was virus, or whether in fact it had contained associated material in the same size range as the virus. This was particularly the case with Newcastle-disease virus, where purified preparations showed particles of similar size but of widely differing structure. The variability of Newcastle-disease virus preparations has been noted by other workers (Cunha, Weil, Beard, Taylor, Sharp \& Beard, 1947; Bang, 1946, $1947,1948)$. There is another objection to the isolation of viruses by centrifugation; it yields a limited range of particle sizes for study. Successful isolation depends on the ability to select particles of a given size range from materials of a wide range of size and density. The technique may have serious limitations when evidence of the mode of virus multiplication is required. Were the process one of simple binary fission the narrow range of size of the particles isolated would be sufficient to contain all the relevant virus particles, and the loss of larger particles during centrifugation would be immaterial. There is, however, no real reason to suppose that this is the case. Should the multiplication be characterized by forms greatly above or below the modal size then losses during centrifugation may well be responsible for our failure to detect essential links in the chain of development. Adsorption to red cells, on the other hand, seemed ideal for our purpose, being presumably independent of size and density of the particles, the two properties predominantly made use of in previous methods of purification.

The intact red cell is too thick for electron microscopy by ordinary transmission methods; and examination of its surface structure by the replica technique is beset by as yet unsolved difficulties. However, Wolpers (1941) has shown that the ghosts of human erythrocytes lysed osmotically can be successfully photographed in the electron microscope, with or without fixation by osmic acid. Likewise, Dawson \& McFarlane (unpublished) found the laked avian erythrocyte to possess ideal thickness and contrast properties for electron microscopy. For example, in the photograph of a shadowcast preparation in Pl. 1, fig. 1 the folds and also a considerable degree of fine structure in the membrane are well shown. The membrane is approximately $6 \mathrm{~m} \mu$ thick and is therefore quite thin enough to act as a support for virus particles in transmission, as distinct from replica, studies of virus adsorption. Influenza virus adsorbed on such laked cell membranes gave a clear picture of the virus bodies (Dawson \& Elford, 1949), and we have now made similar studies of all the viruses in this group. During the course of the work Heinmets (1948) published some micrographs of purified influenza virus adsorbed on the avian and human erythrocytes. He was concerned solely to demonstrate the adsorption and examined only purified virus material; no data on the quantitative aspects of the adsorption phenomenon were reported. 


\section{METHODS AND MATERIALS}

Fowl red cells were haemolysed with saponin according to the method of Dounce \& Lan (1943) and the laked cells washed thoroughly with $0.9 \%$ saline $\mathrm{M} / 33$ phosphate $\mathrm{pH} 6.7$. After a given period of contact with virus at $0^{\circ}$ the cells were centrifuged and the deposit, resuspended in $0.9 \%$ saline, fixed in $0.1 \%$ osmic acid and washed with distilled water several times by spinning at 500 r.p.m. for $5 \mathrm{~min}$. and discarding the supernatant fluid. The cells were then mounted directly from the'distilled water suspension on ordinary electron microscope disks with supporting collodion film. As the suspension settles on the film the concentration of cells is checked under the optical microscope, and adjusted by pipetting off the excess suspension or adding more of the original material until there are about six cells deposited in each field of $0.01 \mathrm{~mm} .^{2}$. The specimen is then examined by direct transmission or after shadow-casting with gold or palladium. Where the laked cells are in high concentration there is considerable folding of the membrane during the drying. For counts of particles on the membrane it is always possible by careful mounting to obtain flat uniform fields with minimum folding. The area to which the count relates is measured on the photographic plate by a planimeter and the number of virus particles per square micron $\left(\mu^{2}\right)$ of the cell surface determined.

Strains of viruses. The following viruses were tested.

The PR 8 strain of influenza $A$ and the Lee strain of influenza B. Each has been passaged in 10-day eggs and harvested on the twelfth day.

Newcastle disease-'Herts' strain kindly supplied by Dr T. M. Doyle.

Fowl plague-'Dutch' strain also supplied by Dr T. M. Doyle.

Newcastle-disease virus and fowl-plague virus were each passaged in the allantois in 10-day hen's eggs and the virus harvested after $36 \mathrm{hr}$. incubation at $37^{\circ}$.

Mumps-Enders EMA 41 strain kindly sent to us by Dr H. Koprowski. This virus was passaged in the allantois in 8-day eggs and harvested after 4 days' incubation at $35^{\circ}$.

Virus assay. The red-cell agglutination was carried out according to Salk (1944). The limiting infective dilution (L.I.D.) was determined by inoculating serial 10-fold dilutions of the virus into eggs of the appropriate age (see Beveridge \& Burnet, 1946).

Concentrations of cells. Red and laked cell suspensions were counted in a haemocytometer cell.

Abbreviations. [virus] and [cells]=concentration of virus and of cells respectively.

\section{RESULTS}

The adsorption of influenza viruses

Influenza virus was readily adsorbed from the unpurified allantoic or amniotic fluid of infected hens' eggs. Pl. 2, fig. 3 and Pl. 4, fig. 9, show cell membranes on which influenza $B$ virus has been adsorbed, and Pl. 1, fig. 2 and Pl. 4, fig. 8 the corresponding micrographs of influenza $A$. The virus particles occur singly 
and in groups in the membrane surface and are not distributed in any obvious pattern. There is very little interference caused by adsorbed non-viral allantoic material, which is relatively small both in size and quantity. No particles of the size and shape of influenza virus were seen on cells exposed to allantoic fluid from normal eggs; and chemical analysis for protein confirmed that the amount of adsorbed material was small. With concentrated preparations of influenza virus it was possible to pack the surface of the membrane with virus particles as illustrated in $\mathrm{Pl}$. 2, fig. 4. The packing arrangement gives no obvious indication of any geometric pattern of receptor groups on the membrane surface. Admittedly the arrangement is complicated by the fact that we observe simultaneously the particles which lie on the upper surface of the specimen and also those underneath, which are covered by two thicknesses of cell membrane. The results do indicate, however, that adsorption is the outcome of a direct interaction between each virus particle and the cell membrane, and is not a process whereby the initial adsorption of a few virus particles provides foci for the aggregation of more virus particles in that area; that is, a process analogous to ordinary chemical crystallization. Virus adsorbed at $0^{\circ}$ may be eluted by incubating at $37^{\circ}$. Such eluted virus can be readsorbed on to fresh membranes. Chemical analysis and the examination of a series of micrographs both show that there is less associated non-viral protein on the cell membrane after adsorption of eluted virus. Influenza virus inactivated for $30 \mathrm{~min}$. at $56^{\circ}$ is readily adsorbed, but cannot subsequently be eluted by incubation; this confirms the findings of Hirst (1942). There were no morphological differences between influenza $\mathbf{A}$ virus particles adsorbed directly from allantoic fluid, or after heat-inactivation; or readsorbed after elution.

Virus was adsorbed on to intact red cells which were then haemolysed with saponin. The membranes were quite free of virus; in the laking process the virus had apparently been eluted. This result emphasized the need of very thorough washing of the laked cells in order to remove traces of saponin which could inhibit subsequent adsorption. Influenza virus was successfully adsorbed in the range of maximum stability, $\mathrm{pH} 5 \cdot 5-7 \cdot 6$. We found that both virus and cells could be stored at $0^{\circ}$ for several weeks without serious deterioration, as judged from subsequent micrographs.

\section{The adsorption of the viruses of Newcastle disease, fowl plague and mumps}

Our earlier studies of these viruses (Elford et al. 1948) were made with centrifugally purified preparations. Elementary particles of the virus of fowl plague were relatively uniform in size and shape, but those of mumps and Newcastle-disease viruses were variable both in size and morphology. The correct interpretation of this apparent pleomorphism has hitherto been uncertain. Does it represent a variable virus structure, or is it largely induced by excessive manipulation of the virus during purification? Investigation of the effects of various electrolyte concentrations on the dispersion of Newcastledisease virus by Bang $(1947,1948)$ and our own observations on purified 
concentrates of the virus (Elford et al. 1948) led to the conclusion that much of the variability in form was due to deleterious treatment of the virus. The lakedcell adsorption technique gives further evidence. The mean sizes of all the viruses in the group (Table 1) and the scatter of the sizes (Fig. 1) were determined. In each instance 200 virus particles were measured from micrographs of unshadowed specimens. When particles were oval in outline the larger

Table 1. Comparative data on the sizes of the viruses of the influenza, Newcastle disease, fowl plague and mumps group, in dried preparations

\begin{tabular}{|c|c|c|c|}
\hline Virus & Strain & General morphology & $\begin{array}{c}\text { Mean size and } \\
\text { standard deviation }(\mathrm{m} \mu)\end{array}$ \\
\hline Influenza A & P.R. 8 & $\begin{array}{l}\text { Round bodies with sharp } \\
\text { outline }\end{array}$ & $90 \pm 11 \cdot 5$ \\
\hline \multirow[t]{2}{*}{ Influenza B } & Lee & $\begin{array}{l}\text { Round bodies with sharp } \\
\text { outline }\end{array}$ & $103 \pm 8$ \\
\hline & & Associated long forms & $\begin{array}{c}110 \\
\text { (up to } 4 \mu \text { long) }\end{array}$ \\
\hline \multirow[t]{2}{*}{ Fowl plague } & Dutch & $\begin{array}{l}\text { Round bodies with rather } \\
\text { diffuse outline; apparently } \\
\text { flattened }\end{array}$ & $101 \pm 16$ \\
\hline & & Associated long forms & $\begin{array}{c}80 \text { width } \\
\text { (up to } 6 \mu \text { long) }\end{array}$ \\
\hline $\begin{array}{l}\text { Newcastle } \\
\text { disease }\end{array}$ & Herts & $\begin{array}{l}\text { Round and oval bodies with } \\
\text { sharp outline }\end{array}$ & $193 \pm 28$ \\
\hline Mumps & $\begin{array}{l}\text { Enders } \\
\text { E.M.A. } 41\end{array}$ & $\begin{array}{l}\text { Round and oval bodies; } \\
\text { appreciably flattened }\end{array}$ & $179 \pm 28$ \\
\hline
\end{tabular}

dimension was measured. The measurement (microscope calibration) is accurate to within $\pm 5 \%$ of the true value. It is noteworthy that the figures are for virus fixed with osmic acid. Whether air-dried, osmic-acid fixed material, or air-dried unfixed material more nearly represents the virus in its normal state is possibly rather an academic question. The shrinkage occurring when fixed material is dried is generally more symmetrical than is the case with unfixed material. The measurements in Table 1 and Fig. 1 are reliable because they are made on preparations subjected to the minimum amount of manipulation.

With mumps (Pl. 3, fig. 7) and Newcastle-disease (Pl. 3, fig. 6) viruses there is indeed a rather wide variation in the size of adsorbed particles. Mumps virus dries very flat on the membrane with an overall size range, 100-260 $\mathrm{m} \mu$, and a mean of $179 \pm 28 \mathrm{~m} \mu$ (Fig. 1). Newcastle-disease virus dried in a variable manner. Sometimes the shadowed image indicated a round flat body and at others an ovoid shape. The range of particle size was $140-270 \mathrm{~m} \mu$ with the mean $193 \pm 28 \mathrm{~m} \mu$.

The whole question of morphological variation among viruses must clearly be reconsidered in the light of the striking micrographs of fowl-plague and influenza $\mathrm{B}$ viruses directly adsorbed from freshly harvested allantoic fluid. In addition to the normal round bodies of fowl-plague virus $101 \pm 16 \mathrm{~m} \mu$ in diameter (PI. 3, fig. 5), there are filaments up to $6 \mu$ in length and averaging $80 \mathrm{~m} \mu$ in width, which in some instances are terminated by a spherical mass $100 \mathrm{~m} \mu$ in diameter. 'These filaments would be lost during filtration and spinning 
and we have been able to detect them only by the adsorption method. Pl. 2, fig. 3 and $\mathrm{Pl}$. 4, fig. 10 show the analogous but rather less-striking result with influenza $B$ virus. Long forms in influenza-infected allantoic fluid have already been reported by Mosley \& Wyckoff (1946) for the PR 8 and Weiss strains of influenza $\mathbf{A}$ and the Lee strain of influenza $\mathbf{B}$. The morphological and developmental significance of these anomalous forms can be elucidated only by examination of virus material in various stages of development. Up to the
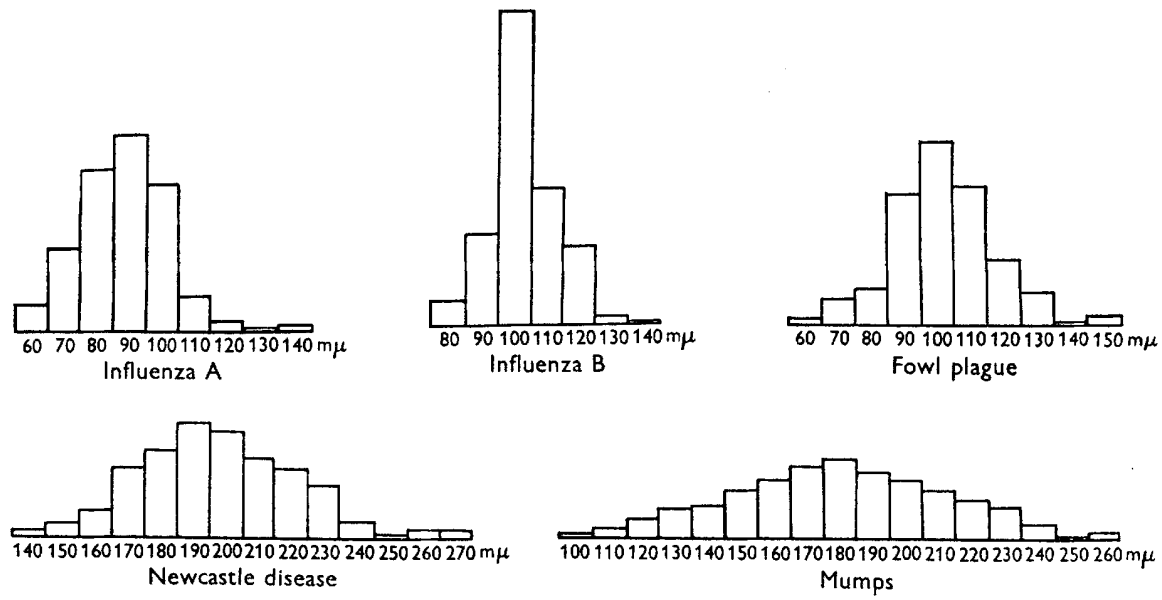

Fig. 1. The distribution of particle sizes in preparations of influenza and related viruses. The figures refer to the mean size value in $\mathrm{m} \mu$ for each rectangle in the histograms.

present no such filamentous structures have been encountered in normal allantoic fluid and they are not associated in any way with the original red-cell preparation. The fact that long forms are, like the round particles, adsorbed to the red cell suggests that both have a similar surface structure. Furthermore, these long forms are not a feature only of aged and partially degenerated virus, since all our observations were made on fresh material. We have also succeeded in eluting both long and round forms from adsorbed heat-treated fowl-plague virus, as happens with influenza virus, by treatment with specific antiserum. This constitutes additional evidence of a similarity in the surface structure of the round and long forms.

\section{The factors influencing adsorption}

Virus concentration. A constant number of laked red cells was added to a given volume of each of three suspensions of influenza virus at different concentrations. After $15 \mathrm{~min}$. contact at $0^{\circ}$ the cells were centrifuged and the virus adsorbed on the membranes counted. Table 2 gives the results of such an experiment with influenza $\mathrm{B}$ virus (see also Pl. 4, figs. 9-11).

Clearly the specific adsorption is directly proportional to the concentration of virus for the prevailing conditions, and this relationship can be expected to hold so long as the ratio [cells] to [virus] is such that full saturation of the membrane surface is not approached. 
Cell concentration. The results with a wider range of cell and virus concentrations are given in Table 3, which records experiments all done with one batch of red cells. With the concentrated virus, prepared by adsorption from allantoic fluid on to laked cells at $0^{\circ}$, followed by elution at $37^{\circ}$ in a reduced

Table 2. The effect of virus concentration on the number of influenza $\boldsymbol{B}$ particles adsorbed per unit area of red-cell membrane, in a suspension of laked red cells $\left(5 \times 10^{6} / \mathrm{ml}\right.$.)

$\begin{array}{ccccc}\begin{array}{c}\text { Virus } \\ \text { Dilution of } \\ \text { virus (eluate) }\end{array} & \begin{array}{c}\text { Aaemagglutinin } \\ \text { titre }\end{array} & \begin{array}{c}\text { Area } \\ \text { counted }\left(\mu^{2}\right)\end{array} & \begin{array}{c}\text { Particle } \\ \text { count }\end{array} & \text { Particles } / \mu^{2} \\ 10^{0} & 12800 & 40 \cdot 7 & 910 & 22 \\ 10^{-1} & 1280 & 71 \cdot 5 & 139 & 1 \cdot 9 \\ 10^{-2} & 128 & 64 \cdot 6 & 13 & 0 \cdot 2\end{array}$

Table 3. The effect of variation in concentration of influenza $B$ virus and laked cells on the number of virus particles adsorbed per unit area of red-cell membrane

\begin{tabular}{|c|c|c|c|c|c|c|}
\hline $\begin{array}{l}\text { Exp. } \\
\text { no. }\end{array}$ & $\begin{array}{l}\text { Haemag- } \\
\text { glutinin } \\
\text { titre of } \\
\text { virus }\end{array}$ & $\begin{array}{l}\text { Laked cells } \\
\text { (million } / \mathrm{ml} \text {.) }\end{array}$ & $\begin{array}{c}\text { Particle } \\
\text { count }\end{array}$ & $\begin{array}{c}\text { Area } \\
\text { counted } \\
\left(\mu^{2}\right)\end{array}$ & Particles $/ \mu^{2}$ & $\begin{array}{c}\text { Percentage } \\
\text { decrease in } \\
\text { haemagglutinin } \\
\text { titre after } \\
\text { adsorption }\end{array}$ \\
\hline 1 & 32000 & 12 & 844 & 28 & 30 & $90-99$ \\
\hline 2 & 32000 & 3 & 723 & 25 & 29 & $<50$ \\
\hline 3 & 32000 & 0.75 & 580 & $16 \cdot 4$ & 35 & $<50$ \\
\hline 4 & 3200 & 12 & 110 & 28 & 4 & 30 \\
\hline 5 & 3200 & 3 & 340 & 25 & 14 & $<50$ \\
\hline 6 & 3200 & 0.75 & 543 & 21 & 26 & $<50$ \\
\hline 7 & 3200 & 3 & 468 & 21 & 22 & - \\
\hline 8 & 3200 & 3 & 476 & $13 \cdot 5$ & 35 & - \\
\hline
\end{tabular}

Exps. $1-7$, contact $15 \mathrm{~min}$. at $0^{\circ}$; $\operatorname{Exp} .8,15 \mathrm{~min}$. at $37^{\circ}$.

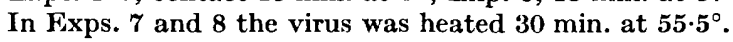

volume of $0.9 \%$ saline-phosphate $\mathrm{pH} 6.7$, the number of particles adsorbed per unit area, within the error of measurement, was the same for each [cell]; i.e. the adsorption capacity of the receptors on the cell surface had been saturated in each instance. When the [virus] was diminished 10-fold, saturation was approached only for the lowest [cells]. Several experiments have yielded a definite saturation value which varies widely with different batches of cells.

Heat treatment of virus. Virus heated for $30 \mathrm{~min}$. at $55.5^{\circ}$ was adsorbed, under otherwise similar conditions, to a greater extent than was normal virus (Table 3, Exps. 5 and 7 ). The increase was even more pronounced when the heattreated virus was adsorbed at $37^{\circ}(\operatorname{Exp} .8)$. We have already noted that heated virus is not readily eluted; so that the dynamics of its adsorption differ from those of normal virus. Since the time of contact between virus and cells in our experiments was constant throughout, the results indicate that in the absence of spontaneous elution the rate of adsorption increases with increase in temperature. The improved adsorption of heat-treated virus was also manifest when three successive amounts of virus were adsorbed on the same cells (Table 4). 
There is clearly an increment in the number of particles adsorbed for each successive treatment in subsaturation conditions. Similar experiments with normal fresh virus gave rather inconsistent figures. In some cases there was no apparent increase in the count of adsorbed virus, and in others there was a slight rise. The complicating factor of spontaneous elution superimposed on the effect of different [virus]: [cells] ratios probably accounted for the variable results, and their evaluation would demand far more extensive studies.

Table 4. The effect of successive adsorptions of heat-treated influenza $B$ virus upon the same red-cell membrane, on the number of virus particles adsorbed per unit area

$\begin{array}{cccc}\begin{array}{c}\text { No. of } \\ \text { adsorption }\end{array} & \begin{array}{c}\text { Particle } \\ \text { count }\end{array} & \begin{array}{c}\text { Area } \\ \text { counted }\left(\mu^{2}\right)\end{array} & \text { Particles } / \mu^{2} \\ 1 & 124 & 25 & 5 \\ 2 & 110 & 12 & 9 \\ 3 & 136 & 8 & 17\end{array}$

[Virus]; haemagglutinin titre 1600 initially, 800 after heating. $[$ Cells $]=3 \times 10^{6} / \mathrm{ml}$. Contact $=15 \mathrm{~min}$. at $0^{\circ}$.

Table 5. The effect of temperature on the degree of adsorption of influenza $B$ virus per unit area of laked red-cell membrane

\begin{tabular}{|c|c|c|c|}
\hline $\begin{array}{c}\text { Temperature } \\
\left({ }^{\circ} \mathrm{C} .\right)\end{array}$ & $\begin{array}{l}\text { Particle } \\
\text { count }\end{array}$ & $\begin{array}{c}\text { Area } \\
\text { counted }\left(\mu^{2}\right)\end{array}$ & Particles $/ \mu^{2}$ \\
\hline 0 & 310 & 19 & $16 \cdot 5$ \\
\hline 20 & 288 & 15 & 19 \\
\hline 37 & 270 & $25 \cdot 5$ & $10 \cdot 5$ \\
\hline
\end{tabular}

[Virus]; haemagglutinin titre $=1600$.

$[$ Cells $]=1.5 \times 10^{6} / \mathrm{ml}$. Contact $=15 \mathrm{~min}$.

The effect of temperature. The effect of temperature on the degree of adsorption of normal influenza $B$ virus from allantoic fluid was also investigated (Table 5).

The figures are consistent with the view that there are two opposing processes with positive though different temperature coefficients. The rate of elution at $0^{\circ}$ is relatively small; it increases much more rapidly with temperature than does the rate of adsorption, appearing to overtake it in the region of $20^{\circ}$, where the number of particles remaining adsorbed after $15 \mathrm{~min}$. is maximum.

The influence of time; the adsorption isotherm. Mixtures of virus and laked cells, kept at $0^{\circ}$ with periodic shaking, were sampled at intervals and the adsorption curves for each of the viruses was determined for periods up to $2 \mathrm{hr}$. In some instances preliminary observations on the rate of elution were made.

(i) Influenza virus. Our preliminary results with two strains of influenza virus confirmed the findings of Hirst (1942). The curves for influenza $A$ and influenza $\mathrm{B}$ are given in Fig. $2 a$. The rate of adsorption of the $\mathrm{B}$ strain was such that no significant increase in virus concentrations on the cell membrane was noted after $\mathbf{5} \mathrm{min}$. With the $\mathbf{A}$ strain, on the other hand, adsorption did not approach completion until after $100 \mathrm{~min}$. 
(ii) Fowl-plague virus. The particle count/unit area of membrane reached a steady high value after $10 \mathrm{~min}$., suggesting that saturation had been reached for the prevailing conditions (Fig. $2 b$ ).

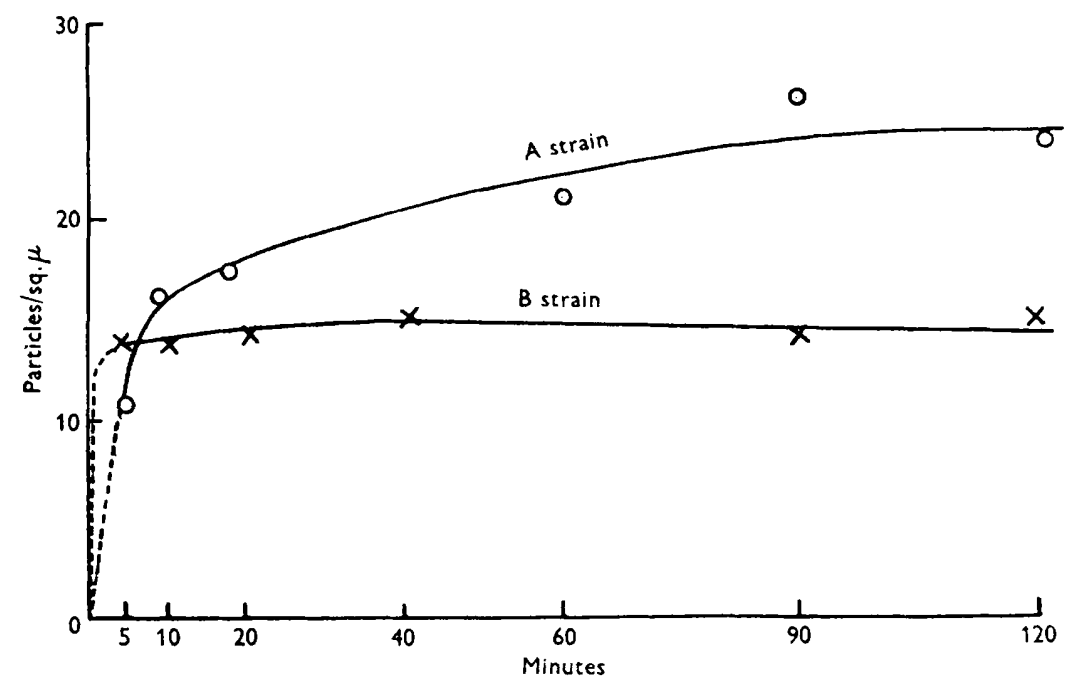

Fig. 2(a). The adsorption isotherm for influenza virus strains A and B.

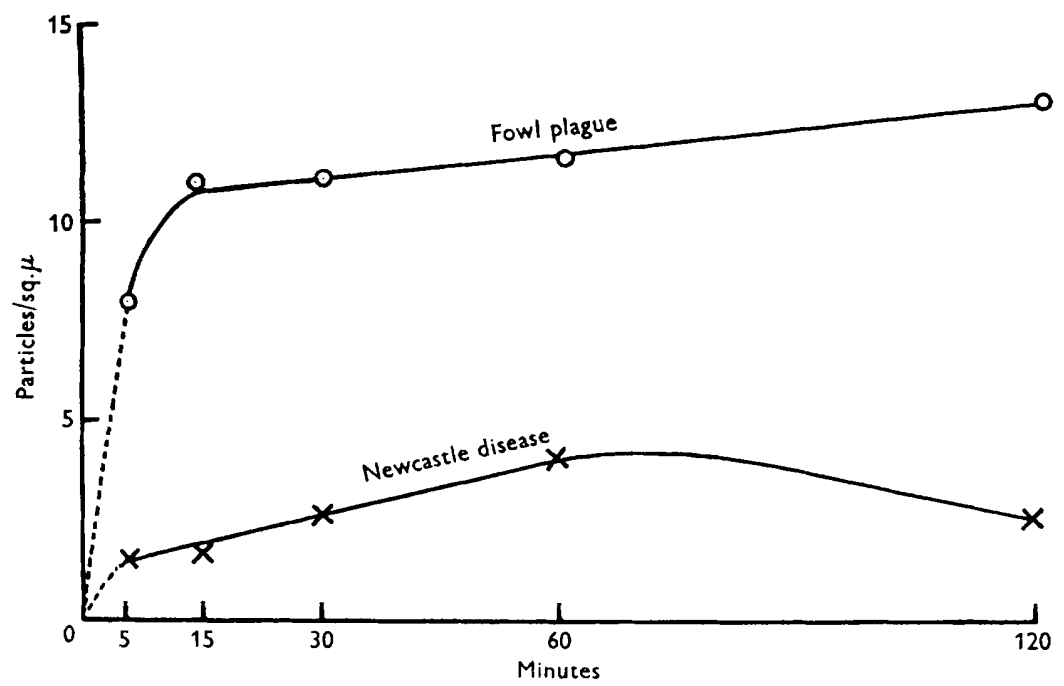

Fig. 2(b). Adsorption isotherm for Newcastle-disease virus and for fowl-plague virus.

(iii) Newcastle-disease virus. The adsorption in this case was a maximum after $60 \mathrm{~min}$. and then decreased to the extent of nearly $50 \%$ during the next hour (Fig. 2b).

(iv) Mumps virus. Our obscrvations for mumps virus indicate that here, too, the adsorption is slow.

The adsorption curves are for freshly harvested unheated virus, and therefore 
portray the combined effect of adsorption and elution at $0^{\circ}$. The form of the curve for Newcastle-disease virus suggests that the rate of elution is in this case appreciable even at this low temperature.

Elution of virus. Our observations on the elution of the individual viruses indicate that whereas influenza $B$ virus is eluted to the extent of $90 \%$ or more in $1 \mathrm{hr}$. at $37^{\circ}$, Newcastle-disease and fowl-plague viruses are much more tenacious, $25 \%$ still remaining on the membrane after $1 \mathrm{hr}$. Accepting the current view that elution is determined by enzymic action as a result of which the receptor linkage is destroyed, we can explain these findings by assuming that a proportion of the virus particles are without enzyme, or, that the enzyme varies in its specificity and stability from virus to virus. $\mathbf{A}$ further point arising from our elution experiments concerns the appearance of the membrane after the elution of virus. No alteration could be detected. We conclude that the receptor groups are relatively small elements in discrete areas of the cell membrane.

\section{DISCUSSION}

The adsorption method of preparing viruses for electron microscopy has three outstanding advantages. (1) It is simple and saves much time and effort in preparing specimens. Viruses that ordinarily require $2-3 \mathrm{hr}$. high speed centrifugation for their sedimentation, can, when adsorbed on the red-cell membranes, be deposited in 5 min. at low speeds. The specimens may thus be quickly washed several times and mounted without any harsh treatment. (2) The specificity of the adsorption means that viruses, in freshly harvested infected fluids, are quickly freed from protein and other products. The possibility thus afforded of examining the virus at quite short intervals after the initiation of infection is being exploited in the hope of obtaining new evidence of the morphology of viruses during the most active phase of multiplication. (3) Direct counts of the virus particles actually adsorbed on the membranes can be used to explore certain cell-virus relationships under varied conditions. The virus is well distributed on the membranes and there is no tendency to the aggregation that frequently mars preparations made by drying directly on a collodion film.

The method is limited to viruses that can be adsorbed on the red-cell membrane. We are, however, studying the dissociated haemagglutinins, as obtained with vaccinia virus, with promising results. The structure of the membrane itself is also under investigation, and already some direct transmission micrographs of the osmic-acid fixed membrane have given evidence of a strongly electron-adsorbing material distributed in the form of a relatively open network within the membranes.

A full understanding of the interaction of laked red cell and virus demands more data concerning the spontaneous elution of virus, but the facts so far established clearly indicate the extent to which the net adsorption is dependent upon virus concentration, cell concentration, time and temperature. The membrane appears to possess a definite specific adsorption capacity. This saturation level varies with the particular batch of cells and their age, i.e. time 
of storage at $0^{\circ}$ after preparation. For freshly made suspensions the observed average saturation values in experiments with influenza $B$ was close to $40 / \mu^{2}$, with a variation of as much as $\pm \mathbf{2 0}$. The mean particle diameter for influenza $\mathrm{B}$ virus was $103 \mathrm{~m} \mu$. Hence the area covered by forty such particles is $0.33 \mu^{2}$ indicating that $67 \%$ of the membrane surface remains uncovered. Hanig (1948), working with PR 8 influenza A and using haemagglutinin titres for deducing the adsorption on intact red cells, calculated that only $1 / 80$ th of the surface was covered at saturation, the number of virus particles/cell being 298. The saturation level of adsorption in Exp. 1, Table 3, with influenza $B$ was 30 per $\mu^{2}$ with a [cells] $=12 \times 10^{6} / \mathrm{ml}$. The total surface area of a laked fowl red cell from electron micrographs is $1.8 \times 10^{-6} \mathrm{sq} . \mathrm{cm}$., and the average number of virus particles adsorbed/cell is calculated to be $5 \cdot 4 \times 10^{3}$. Therefore the total virus adsorbed from $1 \mathrm{ml}$. suspension was $6.5 \times 10^{10}$, and this from the haemagglutination test represented $90-99 \%$ of the virus. Unfortunately, we had not determined the limiting infective dilution of this virus suspension. Clearly here is a means of determining the approximate number of virus particles $/ \mathrm{ml}$. We found it possible to pack considerably more particles on the surface by using a sufficiently concentrated suspension of virus. The lack of any geometric arrangement in such close packing suggests that the excess virus may be held non-specifically by aggregation rather than by attachment to residual receptor groups. Alternatively, the force of attraction between the receptors and virus might vary because the receptor groups are not all equally accessible; for example, they might be distributed in more than one plane.

A knowledge of the adsorption and elution curves for the viruses is essential for devising optimum conditions of purification. We have already pointed out the advantages of using laked cell suspensions instead of intact red cells (Elford et al. 1948). Furthermore, the data of adsorption and elution may form a useful basis for characterizing viruses within the group; even strains of influenza viruses $\mathbf{A}$ and $\mathbf{B}$ behave quite differently.

The observations that will probably arouse great interest are those revealing the long forms associated with fowl-plague and influenza $B$ viruses. The existence of the filamentous forms does not alter the fact that the round elementary particle is the morphological unit, capable, when injected into the host, of multiplying and giving rise to the typical symptoms of the particular disease. It would be premature to regard these long forms as being a phase in virus multiplication, but their close association with the elementary virus bodies in freshly harvested infective fluids and the similarity of their surfaces with regard to combination with red cells or antibody are suggestive. Inspection of the lower membrane in $\mathrm{Pl}$. 2, fig. 3 reveals both circular bodies of influenza $\mathrm{B}$ virus, $100 \mathrm{~m} \mu$ in diameter, and rod-like forms up to $750 \mathrm{~m} \mu$ long. We are trying to determine whether or not these rods represent a stage in the development of the still larger forms up to $2 \mu$ long that are occasionally seen.

The ratio of the sizes of the largest to the smallest forms of the elementary virus bodies is much the same for all members of this group, namely 2 to $2 \cdot 5: 1$. The scatter of sizes is characteristic for each virus preparation studied. Thus with the viruses of influenza A and B and of fowl plague (Fig. 1) there is 
a definite peak at the mean-size value, whereas with Newcastle-disease virus and particularly with mumps virus the distribution is more even. It is instructive to consider the general character of the dried virus particle on the membrane. The elementary bodies of influenza $A$ and $B$ yielded sharply defined images with appreciable shadows indicating a height: base ratio $(h: b)$ of the order 0.25 and 0.3 respectively; and for fowl-plague virus a ratio of $c .0 \cdot 25$. Newcastle-disease virus was more variable, with a greater proportion of flattened types, the $h: b$ being $c \cdot 0 \cdot 125-0 \cdot 2$. Mumps virus appeared as a flat circular body with an $h: b$ of $c .0 \cdot 1$. The distribution of sizes and the structure and mode of drying of the virus particle are clearly related. Information is needed about the manner in which a particle dries in relation to its structure, density, surface properties, interfacial tension with the supporting surface, and to the medium and conditions of drying. That dried virus particles may yield vastly different images according to their previous treatment is especially clear from our studies of Newcastle-disease and mumps virus purified by four to six centrifugal washings in dilute electrolyte and then mounted and dried on collodion film. The elementary bodies of mumps virus had a mean size $140 \pm 30 \mathrm{~m} \mu$ with an $h: b$ of $c .0 \cdot 3$. The disparity between this and our present figure is doubtless due to factors modifying the process of drying.

Our figures for the sizes and distribution of the elementary particles of influenza viruses $\mathbf{A}$ and $\mathrm{B}$ are in good agreement with those of Sharp, Taylor, McLean, Beard \& Beard (1944) (see also Beard, 1948) and Lauffer \& Stanley (1944). The strain of Newcastle-disease virus we have studied is different from the strains reported upon by American workers (Cunha et al. 1947; Bang, 1946, 1947, 1948), but our latest observations support our earlier views of the morphology of the virus (Elford et al. 1948). We found none of the gross pleomorphism evident in micrographs of centrifuged concentrates of the virus. Our data for mumps virus agree well with those of Weil, Beard, Sharp \& Beard (1948) for the same strain. To our knowledge no electron-microscope studies on fowl-plague virus, other than our own, have as yet been published and the value $101 \pm 16 \mathrm{~m} \mu$ for the mean size of this virus adsorbed on the red-cell membrane accords well with the value $83 \pm 15 \mathrm{~m} \mu$ we obtained earlier from measurements on purified virus.

The investigation of these viruses by the new technique has generally substantiated the conclusions reached in earlier work and greatly clarifies the morphology of these viruses. At the same time it has confirmed the existence of filamentous forms of influenza $B$ virus and demonstrated for the first time similar structure in preparations of fowl-plague virus.

The purified preparations of Newcastle-disease, fowl-plague and mumps viruses examined in our earlier work, we are now convinced, consisted essentially of virus without any large proportion of associated material. Nevertheless, in some instances they may not have been representative of the virus in its original state, in that certain filamentous structures were inadvertently discarded during the purification.

We gratefully acknowledge the help received from our colleagues Drs C. $\mathbf{H}$. Andrewes, F. Fulton and T. H. Flewett in passaging the viruses and conducting 
infectivity tests from time to time. We also thank Dr A. Isaacs for his co-operation in the experiments demonstrating the displacement of influenza virus from the membrane by specific antibody.

\section{REFERENCES}

Bang, F. B. (1946). Filamentous forms of Newcastle virus. Proc. Soc. exp. Biol., N.Y., 63,5 .

BANG, F. B. (1947). Newcastle virus: conversion of spherical forms to filamentous forms. Proc. Soc. exp. Biol., N.Y., 64, 135.

BAng, F. B. (1948). Studies on Newcastle disease virus. I. An evaluation of the method of titration. II. Behaviour of the virus in the embryo. III. Characters of the virus itself with particular reference to electron microscopy. J. exp. Med. $88,251$.

Beard, J. W. (1948). Review: purified animal viruses. J. Immunol. 58, 49.

Beveridge, W. I. B. \& Burnet, F. M. (1946). The cultivation of viruses and rickettsiae in the chick embryo. Spec. Rep. Ser. med. Res. Coun., Lond., no. 256.

Burnet, F. M. (1948). The initiation of cellular infection by influenza and related viruses. Lancet, $\mathrm{i}, 7$.

Cunha, R., Weil, M. L., Beard, D., Taylor, A. R., Sharp, D. G. \& Beard, J. W. (1947). Purification and characters of the Newcastle disease virus (California strain). J. Immuinol. 55, 69.

Dawson, I. M. \& Euford, W. J. (1948). Electron microscope studies on the interaction of certain viruses with fowl red-cell membranes. Nature, Lond., 163, 63.

Dounce, A. L. \& LAN, T. H. (1943). Isolation and properties of chicken erythrocyte nuclei. Science, 97,584 .

Elford, W. J., Chu, C. M., Dawson, I. M., Dudgeon, J. A., Fulton, F. \& Smiles, J. (1948). Physical properties of the viruses of Newcastle disease, fowl plague and mumps. Brit. J. exp. Path. 29, 590.

HANIG, M. (1948). Electrokinetic change in human erythrocytes during adsorption and elution of PR8 influenza virus. Proc. Soc. exp. Biol., N.Y., 68, 385.

Heinmets, F. (1948). Studies with the electron microscope on the interaction of red cells and influenza virus. $J$. Bact. 55, 828.

Hirst, G. K. (1941). The agglutination of red cells by allantoic fluid of chick embryos infected with influenza virus. Science, 94, 22.

Hrnst, G. K. (1942). Adsorption of influenza haemagglutinins and virus by red blood cells. J. exp. Med. 76, 195.

LaUfFer, M. A. \& Stanley, W. M. (1944). Biophysical properties of preparations of PR 8 influenza virus. J. exp. Med. 80, 531 .

McClelland, L. \& Hare, R. (1941). The adsorption of influenza virus by red cells and a new in vitro method of measuring antibodies for influenza virus. Canad. publ. Hlth J. 32, 530.

Mosley, V. M. \& WYCkoff, R. W. G. (1946). Electron micrography of the virus of influenza. Nature, Lond., 157, 263.

SALK, J. E. (1944). A simplified procedure for titrating haemagglutinating capacity of influenza-virus and the corresponding antibody. J. Immunol. 49, 87.

Sharp, D. G., Taylor, A. R., McLean, I. W. Jr., Beard, D. \& Beard, J. W. (1944). Sedimentation velocity and electron micrographic studies of influenza viruses A (PR 8 strain) and B (Lee strain) and the swine influenza virus. J. biol. Chem. 156, 585 .

Weil, M. L., Beard, D., Sharp, D. G. \& Beard, J. W. (1948). Purification and sedimentation and electron micrographic characters of the mumps virus. Proc. Soc. exp. Biol., N.Y., 68, 309.

Wol.PERs, C. (1941). Zur Fein Struktur der Erythrocytenmembran. Naturwissenschaften, 29, 416. 
Journal of General Microbiology, Vol. 3, No. 2

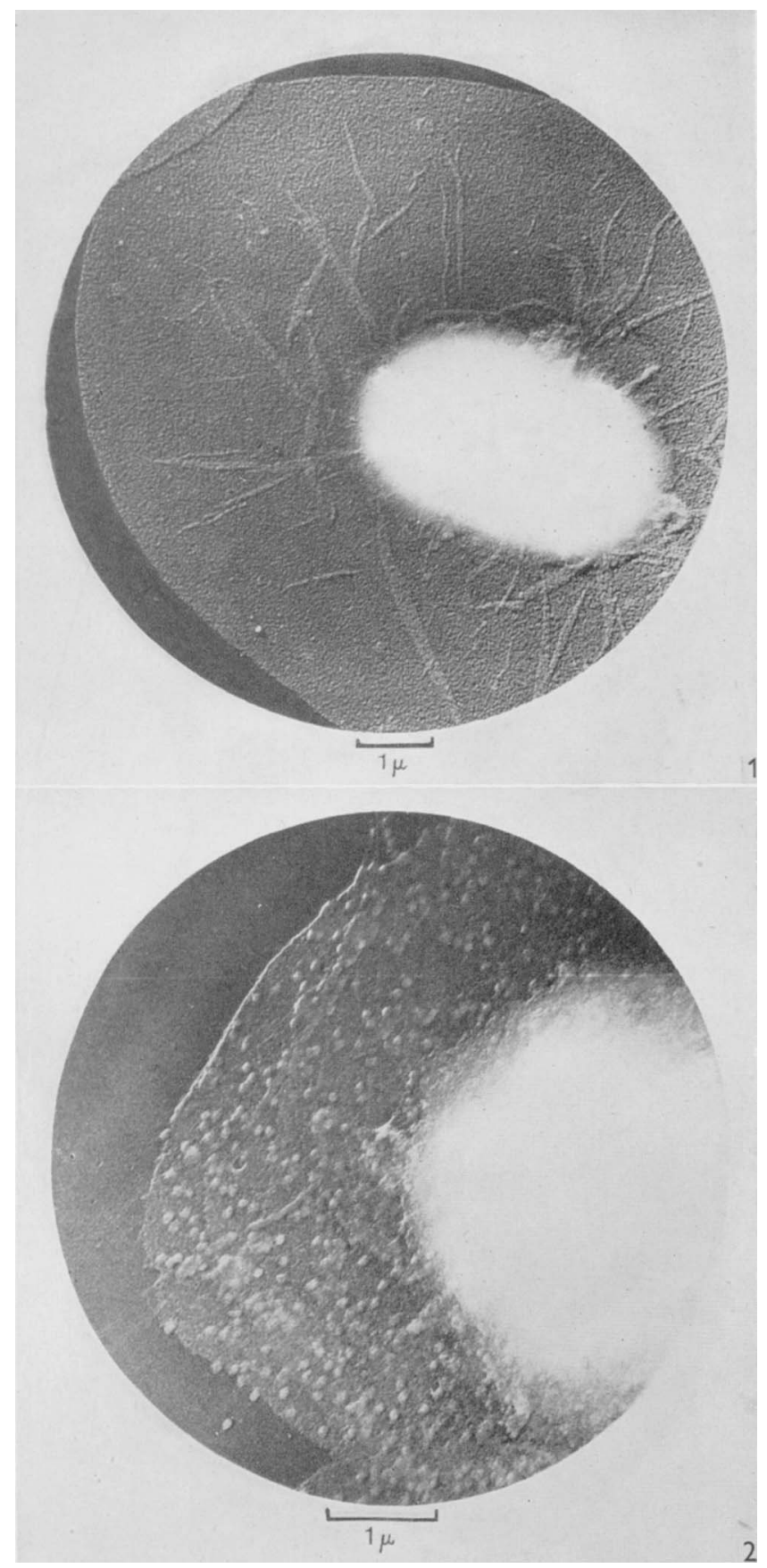

Figs. 1-2

I. M. Dawson and W. J. Elgond-Influlanga and related virlses. Plate 1 
Journal of General Microbiology, Vol. 3, No. 2

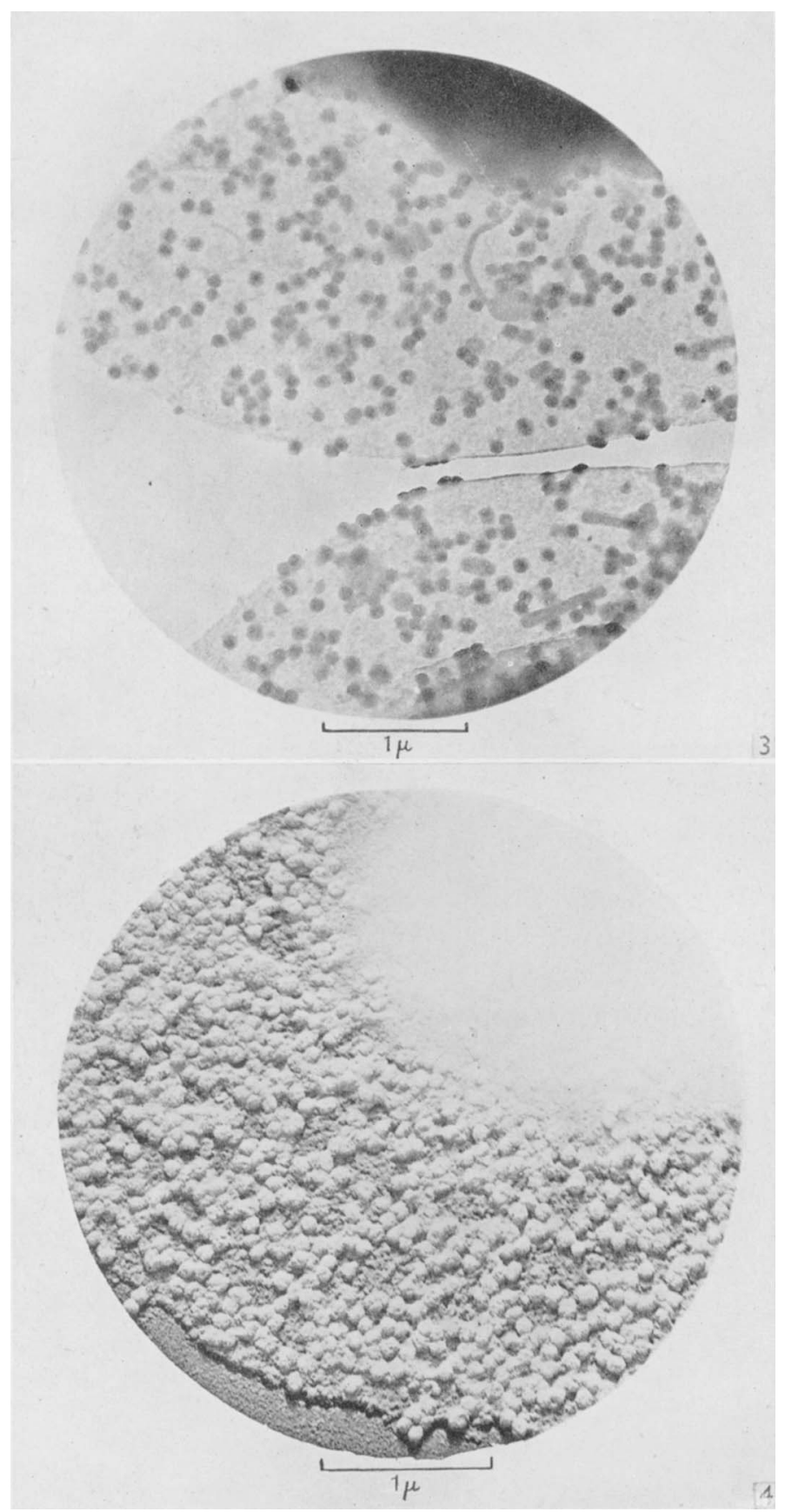

Figs. 3-4

I. M. Dawson and W. J. Elford-Influenza and Retated vimuses. Plate. 2 
Journal of General Microbiology, Vol. 3, No. 2

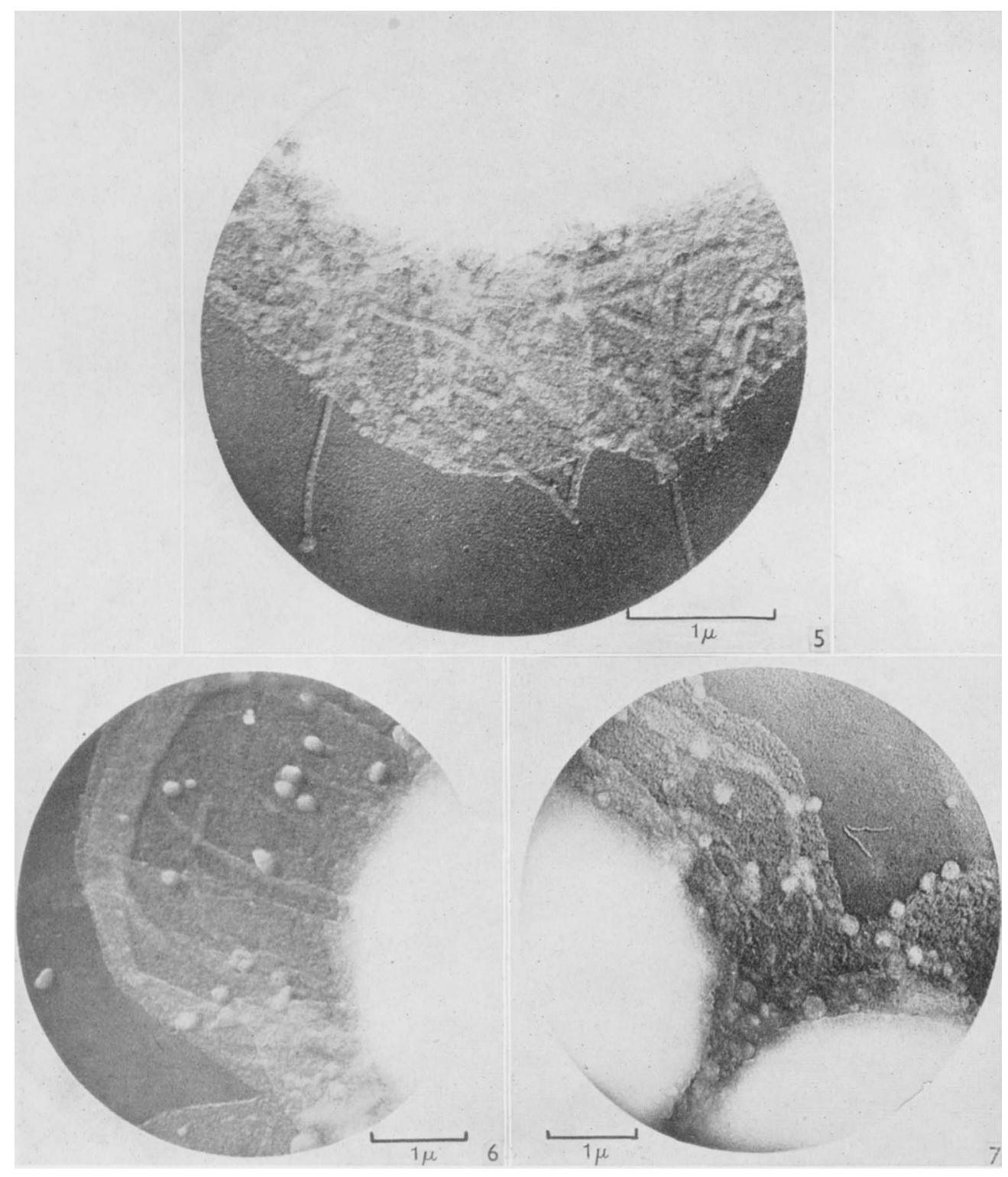

Figs. 5-7

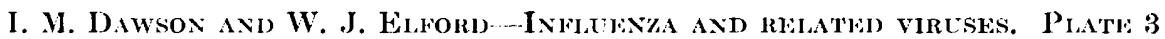


Journal of General Microbiology, Vol. 3, No. 2

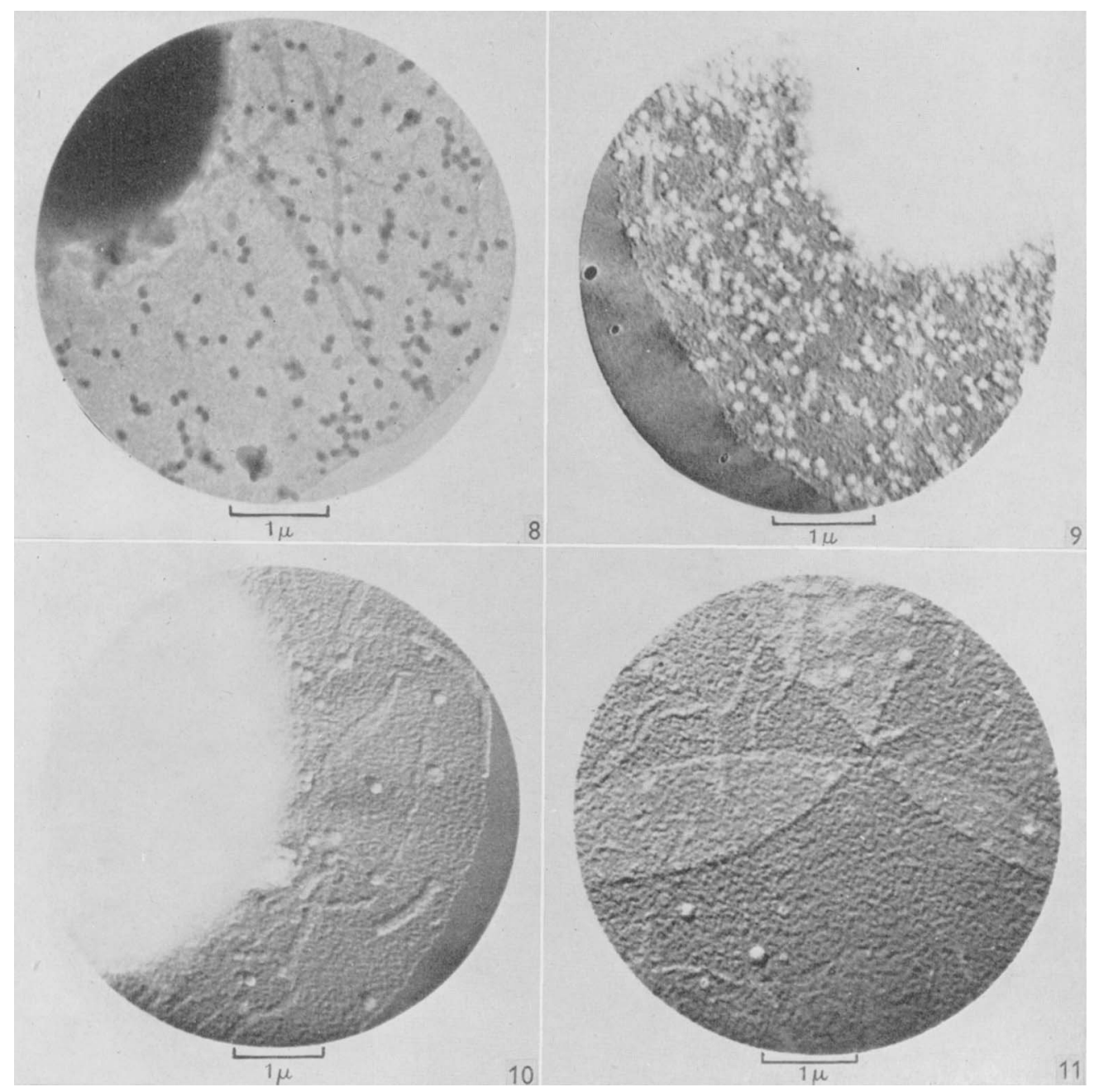

Figs. 8-11

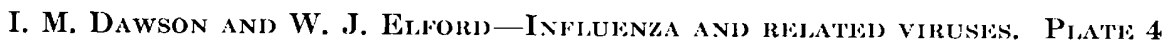




\section{EXPLANATION OF PLATES}

\section{Plate 1}

Fig. 1. Laked fowl erythrocyte shadowcast with palladium. The cell nucleus appears as an oval white body to the right of the field. The cell membrane is folded.

Fig. 2. Laked fowl erythrocyte with adsorbed influenza A virus, shadowcast with palladium. The virus particles appear as small disks on the membrane surface.

Plate 2

Fig. 3. Transmission micrograph of laked fowl erythrocytes with adsorbed influenza $B$ virus.

Fig. 4. Laked fowl erythrocyte with a high concentration of adsorbed influenza $B$ virus to illustrate the random arrangement of virus on close packing. Preparation shadowcast with palladium.

\section{Plate 3}

Fig. 5. Laked fowl erythrocyte with adsorbed fowl-plague virus, showing the round elementary bodies and associated long forms. Preparation shadowcast with palladium.

Fig. 6. Laked fowl erythrocyte with adsorbed virus of Newcastle disease. Preparation shadowcast with palladium.

Fig. 7. Laked fowl erythrocyte with adsorbed mumps virus. Preparation shadowcast with palladium.

Plate 4

Fig. 8. Transmission micrograph of laked fowl erythrocyte with adsorbed influenza A (PR 8) virus.

Figs. 9, 10 and 11. Laked fowl erythrocyte membranes with successive 1/10 dilutions of influenza $B$ virus adsorbed on the membrane. Fig. 10 shows two of the characteristic long forms associated with influenza $B$ virus. These forms are readily distinguishable from folds in the cell membrane also visible in this micrograph. All preparations shadowcast with palladium.

(Received 19 November 1948) 